\title{
ALGORITMICKÁ, POČÍTAČEM PODPOROVANÁ KOMPOZICE A POSTMODERNÍ PLURALISMUS
}

\begin{abstract}
Algoritmická a s tím související počítačem podporovaná kompozice se objevuje na přelomu 50. a 60. let 20. století v okamžiku doznívání jednoty kompozičních metod do té doby vlivné seriální hudby. Následující text tyto jevy vysvětluje s využitím závěrů z filosofie a obecné teorie umění, jako specifické projevy postmodernismu a současně prezentuje algoritmické uvažování coby podstatu Západní hudební kompozice jako takové.
\end{abstract}

\section{Úvodní poznámky}

Pojmem „Computer-Aided/ Assisted Composition“ (CAC) označuje počítačem podporovanou kompozici. Podporou se nemíní podpora jakákoliv, ale podpora $\mathrm{v}$ průběhu kompozičního procesu. Využívají se k tomu obvykle některé z existujících kompozičních software ${ }^{1}$ anebo software zpracovávající vstupní data s cílem vytvářet prvky hudební struktury, např. souzvuky na základě analýzy zvukového spektra ${ }^{2}$ tak, jak je tomu v případě některých skladebných postupů spektrální hudby. Pojem ,algoritmickác“ kompozice pak představuje celou řadu pracovních postupů včetně těch, které přesahují oblast artificiální hudby. V každém případě se jedná o tvorbu hudby ,pomocí metodických procedur, čili určitých předem definovaných postupů [...] do nichž [...] skladatel dále nezasahuje " anebo výsledek jejich užití naopak chápe „pouze jako výchozi“ materiál a tedy materiál „určený $k$ dalšímu zpracováni" ${ }^{3}$ Algoritmy slouží k tvorbě či tvarování hudební

1 Např. software „OpenMusic - a visual programming environment for Computer Assisted Composition" vyvíjený v pařížském Institut de Recherche et Coordination Acoustique/ Musique (IRCAM). Detailní přehled software viz DLOUHÝ 2013, s. 33. lation" vyvíjený rovněž v IRCAM. 
struktury, obvykle k distribuci vybraných parametrů kompozice a potažmo parametrů tónů. Pro možnost využívat, a v průběhu tvưrčího procesu kontrolovat fungování i algoritmů náročných na zpracování, je vazba CAC a algoritmické kompozice logickým, a v praxi častým jevem. V souvislosti s terminologií nabídky CAC software, je možné hovořit o „algoritmu“ jako o souboru „funkci“, přičemž „funkce“ představuje obvykle jeden krok, jednu operaci v rámci tvorby kompozice, např. transpozici souzvuku, která se posléze stane součástí algoritmu coby komplexní metodické procedury.

\section{První autonomní, individuální metody}

Termín „algoritmus“ se ve vztahu s uměním začíná používat od konce 50 let 20. století. ${ }^{4} \mathrm{~V}$ př́ípadě hudební kompozice $\mathrm{k}$ tomu dochází v souvislosti s využíváním výpočetní techniky, která poskytovala možnost rychlého a přesného uplatnění i složitých algoritmů. Zároveň nabízela práci v odlišném prostředí, z čehož vyplynuly také nové skladatelské kompetence a potažmo i nové paradigma kompozice jako takové. I přesto byly první úspěšné, tzn. do podvědomí širší odborné veřejnosti vstupující, vážně míněné pokusy, ovlivněné existencí v té době vlivné estetiky seriální hudby. Př́íkladná je v tomto smyslu skladba Illiac suite (1957) pro smyčcové kvarteto Lejarena Hillera, využívající kromě seriálních postupů i stochastické metody. Nejen v souvislosti s asistencí výpočetní techniky se však širšího uznání a reflexe dostalo tehdejším skladbám Iannise Xenakise, které již představují zcela individuální a od tehdejších tendencí konce padesátých let dosti vzdálené, autonomní kompoziční metody. Taková je např. jeho kompozice $S T / 48$ z roku (1959-1962) využívající jako metodickou proceduru transformace Markovových řetězcůs.

\section{Aspekty tonality jako jevy algoritmické povahy}

Uvedenému pokusu o definování algoritmické kompozice vyhovuje nejen kompozice algoritmická, ale současně jakákoliv jiná hudební kompozice. Platí to i o kompozici vznikající v harmonicko-melodickém slohu. Zmíněná metodická procedura, jejíž výsledky autor vnímá bud'to jako hotové anebo je dále upravuje, může být i užití vybraných souborů pravidel klasicko-romantické harmonie. Takové metodické procedury mají vlastnosti algoritmu. S jejich použitím se tedy dá vyřešit určitá tř́da problémů, např́íklad problém vedení hlasů při rozvodu dominantního septakordu do tónického kvintakordu. Rozvod, stejně jako volné či

$4 \quad$ K historii užívání pojmu viz BURNS, Kristine H. The history and development of algorithms in music composition, 1957-1993: Doctoral dissertation. Muncie: Ball State University, School of Music, 1994.

5 Analýza skladby viz KELLER, Damián - FERNEYHOUGH, Brian. Analysis by Modeling: Xenakis's ST/10-1 080262. Journal of New Music Research, 2004, roč. 33, č. 2, s. 161-171. 
př́śsé spojování akordů, modulace v závislosti na vzdálenosti výchozí a cílové tóniny atd., má své jasně popsané postupy i eventuality. Po užití takových metodických procedur, je možné výsledek prrijmout anebo upravit a oproti všem přssvědčivým argumentům změnit při rozvodu dominantního septakordu stoupání citlivého tónu $\mathrm{k}$ tónické primě na klesání např. $\mathrm{k}$ tónické tercii. Jednoduchý algoritmus pro tvorbu kadence $\mathrm{v}$ elementární čtyřhlasé úpravě a použitelný pro kteroukoliv durovou tóninu, ilustruje Př. $1 .{ }^{6}$

Harmonicko-melodický sloh, a zjednodušeně řečeno, hudba před zjevem hudby atonální, má své metody založené na primárním ,systému formováni““.7 Tímto systémem formování jsou aspekty tonality, které se projevují nejen v rámci dur-mollového systému, ale projevovaly se i daleko dřive již $\mathrm{v}$ rámci modálního jednohlasu. Role finalis a tvarování hlasu v církevním modu, později budování a spojování akordů nebo již zmíněný dominantní rozvod, je ovlivňován existencí tonality, ${ }^{8}$ která kompoziční proces jasně determinuje a formuje. Tonalitu je tedy v širším slova smyslu možné chápat jako primární algoritmus, který, obrazně řečeno, provádí hned několik operací zároveň, a zužuje tak domněle absolutní množství tvůrčích postupů jen na množství relativně neomezené. Nahlíženo prizmatem „obecných kompozičních principu“ je pak tonalita jevem, který determinuje jak ,,princip restrikce/ selekce ${ }^{\text {(69 }}$ tedy počáteční princip výběru materiálu skladby, tak všechny další principy užívané $\mathrm{v}$ rámci vytváření hudební kompozice. Některé $\mathrm{z}$ těchto principů byly dány v podstatě fixně, tedy jako algoritmus neměnný poskytující, díky ,podvědomě puisobicímu citu pro formu [...] téměr námésičný pocit jistoty ${ }^{\text {“ }} .{ }^{10}$ Platí to namátkou o ,principu hierarchie“ $\mathrm{v}$ době formování vídeňského klasicismu, kde „melodiku ovládala prostá diatonická kadenční harmonie určujicí i formu“." ${ }^{11}$

Systém formování je algoritmické povahy a jeho užití zajišt’uje základní soudržnost skladby na makro i mikrotektonické úrovni. Nakládáním s jeho působením se od sebe liší jednotlivé skladatelské školy, směry či osobnosti. Jinými slovy řečeno, ,the Western traditions of tonalism and serialism are based on algorithms that vary in their degrees of mechanization. " ${ }^{12}$

6 Vedení hlasů je převzato z učebnice harmonie, viz KOFROŇ, Jaroslav. Učebnice harmonie. Praha: Editio Supraphon, 1961, s. 41.

7 Pojem „systém formováni““ je pojmem Miloše Honze, kterým označuje „,významný aspekt tonality“ viz HONS, Miloš. K vývoji formového myšlení období rozpadu tonality na počátku 20. století. In K aktuálním otázkám hudebni teorie. Praha: AMU, 2000, s. 47. Byt' pojem „tonalita“ je pojmem 19. století.

9 MEDEK, Ivo - PIŇOS, Alois. Řád hudebni kompozice a prostředky jeho výstavby. Brno: JAMU, 2004, od s. 8.

10 SCHÖNBERG, Arnold. Styl a idea. Praha: Arbor vitae, 2004, s. 86.

11 MEDEK, Ivo - PIŇOS, Alois., op. cit., s. 15.

12 ALSOP, Roger. Exploring the Self Through Algorithmic Composition. Leonardo music journal, 1999, roč. 9, s. 90. 


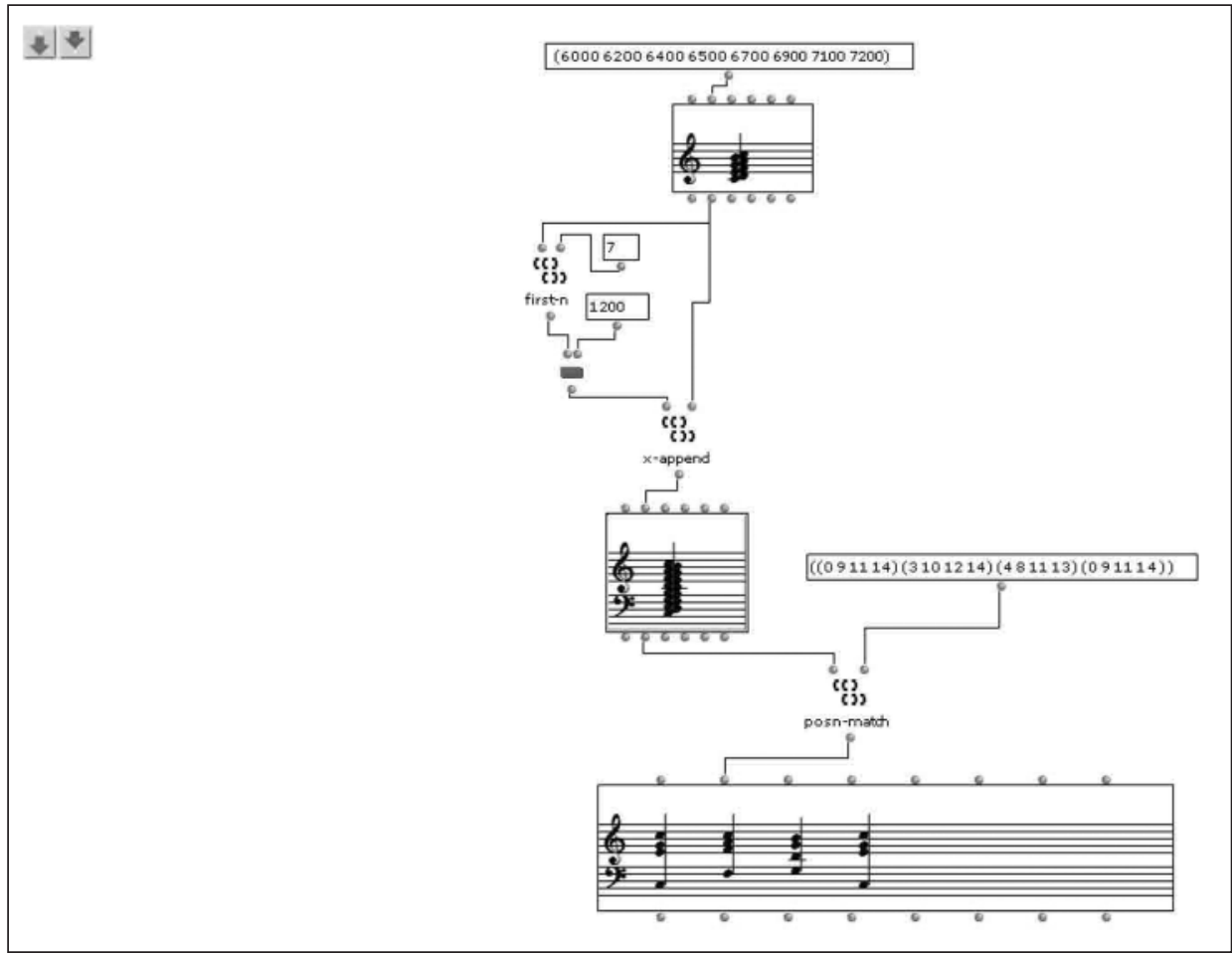

Př. 1. Algoritmus pro tvorbu kadence ve čtyřhlasé úpravě pro kteroukoliv durovou tóninu (pouze výšky tónů, bez rytmu a ligatur spojujících zadržované tóny).Vstupní data, ve formě midicent (mc), představují tóninu C dur v první oktávě (6 $000 \mathrm{mc}=\mathrm{c}^{\prime}, 6200 \mathrm{mc}=\mathrm{d}$, atd., temperovaný půltón $=100 \mathrm{mc}$, celý tón $=200 \mathrm{mc}$ ), čísla vstupující do funkce ,posn-match“ představují pozici dané výšky (stupeň) v řadě výšek (stupnici), podmnožiny obsahují výšky určené ke stavbě akordu. Zdroj: autor, vytvořeno v CAC software OpenMusic.

\section{Chybějící systém}

Hudba atonální žádný takový systém formování, zajištěný aspekty tonality, nemá. Užívaný pojem „,volná atonalita“, pak implikuje jeho absenci, potažmo absenci jevů algoritmické povahy. Dodekafonii je možné vnímat jako logickou reakci na tuto skutečnost a chápat ji v souladu s Arnoldem Schönbergem jako náhradu za „tonální distinkce klasické harmonie“. ${ }^{13}$ Stejně tak je možné nahlížet na seriální hudbu vč. všech jejích vývojových mutací založených na principu řady jako na ,zárodku hierarchie ${ }^{\text {“ }}{ }^{14}$ Dodekafonie, stejně jako seriální hudba, tedy na-

13 SCHÖNBERG, Arnold. Styl a idea. Praha: Arbor vitae, 2004, s. 86.

14 BOULEZ, Pierre. Dnešní hudební myšlení. In Nové cesty hudby, sborník studií o novodobých skladebných směrech a vědeckých názorech na hudbu. Praha: Státní hudební nakladatelství, 1964, s. 136. 
bízí nový systém formování, jenž představuje dnes známé metodické procedury. Algoritmická kompozice dělá totéž, ale na rozdíl od nich neříká př́mo jaké procedury je nutné či vhodné provádět. Algoritmem může být cokoliv a současně nemusí pocházet z primárně hudebního prostředí. ${ }^{15}$ Algoritmická kompozice tedy hovoří jen o nutné přítomnosti systému formování, ovšem jeho výběr nechává na autorovi. Tím pádem nepředstavuje žádný takový soubor metodických procedur, které by měly společný jmenovatel vyúst’ující v definovatelný estetický názor. Namátkou vybraní představitelé mohou být dramaticky odlišní, a přesto mohou reprezentovat jeden proud, který, obrazně řečeno, teče najednou všemi směry. V tomto smyslu je algoritmická kompozice zcela pluralitní.

\section{Pluralita a esoterismus}

Ve vysvětlování obsahu pojmu „postmoderna“ či „postmodernismus“ se jednotliví odborníci z oblasti filosofie, teorie umění a estetiky rozchází. V zásadě se ale shodnou na tom, že postmoderna ,začíná tam, kde konči celek" ${ }^{* 16}$ či jednota. Pro postmoderní dobu a umění je pak specifická „mnoho-uspořádanost bez celkového pravidla“.${ }^{17}$ Postmodernu lze chápat jako ,stav radikální plurality" ${ }^{\text {“18 }}$ a tato pluralita je její ,základni obsah“. Ten sice „,propagovala již sama moderna ${ }^{\text {“19 }}$ ovšem to „co v této moderně bylo elitárního a esoterického je nyní (v postmoderně) exoterické a populárni". ${ }^{\prime \prime}$

Pojmy „esoterické“ a „elitární“ lze chápat ve smyslu ochrany artificiálních hodnost před utilitárními cíli a kýčem, díky nimž byla, slovy Jean- Françoise Lyotarda řečeno: „moderni estetika estetikou vznešeného". ${ }^{21}$ Dělo se tak s výrazným přispěním avantgard a jejich „schopností donekonečna demaskovat triky prezentace ${ }^{\text {“22 }, M o d e r n i ́ m u ~ m y s ̌ l e n i ́ ~ d a ́ v a ́ ~[. . .] ~ f o r m u ~, p r o j e k t ", ~ o ~ n e ̌ m z ̌ ~ H a b e r m a s ~}$ řiká, že zůstal nedokončený،“'23

15 Pokud jako referenční vezmeme CAC software OpenMusic, pak takovými algoritmy jsou např. nelineární diferenciální rovnice Pierre Françoise Verhulsta modelující růst biologické populace nebo rovnice popisující tzv. Lorenzův atraktor, turbulence v kapalinách atp. Otázka ale zůstává, kde jsou hranice tzv. „hudební oblasti“.

WELSCH, Wolfgang. Naše postmoderní doba. Praha: Zvon, 1994, s. 46.

WELSCH, op. cit., s. 166.

WELSCH, op. cit., s. 12.

WELSCH, op. cit., s. 14.

WELSCH, op. cit., s. 116.

LYOTARD, Jean Francois. O postmodernismu. Praha: Filosofický ústav AV ČR, 1994, s. 27.

LYOTARD, op. cit., s. 25.

LYOTARD, op. cit., s. 29. 
$\mathrm{Na}$ jednu stranu je možné vnímat postmodernismus se značným despektem jako „bezbřehý postmodernismus [...] jehož krédem [...] je, že všechno [...] musí být [...], jen zdárně promícháno $v$ coctail $[. .$.$] s hojnými exotickými př́sadami.$ Kř́ží se [...] digitalita a kynismus, nezapomíná se na esoteriku [...], přidá se něco New Age a apokalypsy - a postmoderní hit je hotov. " ${ }^{24}$ Může k tomu dojít díky neschopnosti či neochotě dále se zabývat diskursem uvedeného „projektu“ a prožívat nadále jeho sjednocující „metapřiběhy [...] které (tím) ztrácejí svou přsvědčivost ${ }^{\text {“ }}{ }^{25}$ Podobně kritické postoje mají jeden společný jmenovatel, který by se pro zjednodušení dal obrazně vyjádřit slovem ,vykořeněnost“. Ta se pak může projevovat mícháním uvedeného coctailu či eklekticismem, $v$ jehož souvislosti se pojem ,postmoderna“ začal v druhé polovině 60 . let užívat. ${ }^{26}$

Na druhou stranu lze, podle Wolfganga Welsche, vedle, ,postmodernismu bezbřehosti" pozorovat i ,postmodernismus presnosti [...], který neni obhájcem dezorientovanosti, nýbrž stoupencem pevných pravidel ${ }^{\prime \prime}{ }^{27}$ Nemíchá coctaily a je připraven pokračovat v „projektu“, nebot' „postmoderna sice transformuje modernu, ale neukončuje ji a nevrací do nějaké antimoderny“ ${ }^{28}$ Pod pojmem „pevná pravidla“ můžeme vnímat vědomí o nezbytnosti jejich př́tomnosti, která, v hudební skladbě, reprezentují kompoziční metodu schopnou řešit nejrůznější situace a působit jako „ř́d hudebního díla (jež) tvoři vztahy mezi všemi možnými elementy v kompozici vytvárenými souborem prvku nejrůznější míry obecnosti i hierarchického postaveni" ${ }^{\prime \prime}{ }^{29}$ Volba takového řádu, systému formování a potažmo algoritmu, je pak sice v duchu zmíněné plurality volným aktem skladatele, ovšem jeho př́tomnost je naopak aktem zcela nutným a naplňujícím podstatu algoritmického komponování. Algoritmickou kompozici je možné vnímat coby abstrahování či obnažení samotné povahy hudební kompozice jako takové a současně jako prezentaci postoje, že hudební kompozice je ve svém jádru systémové umění. Takový postoj koresponduje $\mathrm{s}$ algoritmickou povahou tonality a povahou Západní kompozice moderní i předmoderní, kde ,that algorithmic thinking is present in Western composition for at least 1,000 years has been established “. ${ }^{30}$ Díky tomu se algoritmická kompozice dotýká podstaty kompoziční práce a nezavdává přícinu k tomu, aby byla vnímá-

24 WELSCH, op. cit., s. 10.

25 PETříČEK, Miroslav. Úvod do současné filosofie. Praha: Herrman a synové, 1997, s. 173.

26 Pojem „postmoderna“ se objevil v souvislosti s kritikou modernistické, dle tehdejšího diskursu přes př́liš puristické architektury, s cílem formulování „nesouhlasu se zásadním vymycováním nefunkčnich dekorativnich prvkiّ“ ve prospěch svobody „čerpat z celé historické zásoby architektonických koncepcí [...] a radikálního eklekticismu“, viz PECHAR, Jiří. O postmodernismu, smyslu umění a právu na vlastní př́běh. Úvodní studie k publikaci LYOTARD, Jean Francois. O postmodernismu. Praha: Filosofický ústav AV ČR, 1994, s. 5.

27 LYOTARD, op. cit., s. 11.

28 WELSCH, op. cit., s. 161.

29 MEDEK, Ivo - PIŇOS, Alois, op. cit., s. 6.

30 EDWARDS, Michael. Algorithmic Composition: Computational Thinkingin Music. Communications of the acm, 2011, roč. 54, č.7, s. 67. 
na jako „vykořeněný jev“. Současně ji není možné chápat jako nástroj vedoucí a priori k eklekticismu, jenž je bezpochyby jedním z důsledků míchání zmiňovaného coctailu. Stejně jako v př́padě jakýchkoliv postupů, i v rámci algoritmické kompozice se dá takového eklekticismu dosáhnout, coctaile namíchat, ale stejně tak existuje možnost se mu vyhnout. $\mathrm{Z}$ těchto důvodů je vhodné algoritmickou kompozici označit za shora uvedený „postmodernismus přesnosti“, který se jeví být schopen dále rozvíjet ,projekt“ moderny a, slovy T. W. Adorna, jako obhájce jejích vybraných hodnot řečeno, pak vytvářet prostor pro „,novost predstavujicí to, v čem predcházející díla , selhala “..31

\section{Autor algoritmické kompozice}

Jako skladatele pracujícího s algoritmy, by bylo do určité míry možné označit v podstatě kohokoliv komponujícího a současně vědomě užívajícího vybraný soubor metodických procedur. V užším smyslu je ale algoritmické komponování lépe vnímat s vědomím, že se objevuje až na přelomu 50. a 60. let 20. století jako alternativa do té doby využívaných systémů formování. Je to stejná doba, kdy doznívá serialismus jako proud charakteristický jednotnou, a pro jeden okruh skladatelů typickou kompoziční metodou. ${ }^{32}$ Tato jednota, tedy nejen $u$ avantgardních směrů, mizí a objevují se nové, individualizované systémy formování. Příkladem mohou být zmiňované první skladby Iannise Xenakise vznikající v asistenci počítače. Jednotné paradigma kompozice se vytrácí, stejně jako se proměňují kompetence a ,a musical work can be analyzed as a multitude of mental machines. A melodic theme in a symphony is a mold, a mental machine, in the same way as its structure is. These mental machines are sometimes very restrictive and deterministic, and sometimes very vague and indecisive. [...] Certain mechanizable aspects of artistic creation may be simulated by certain physical mechanisms or machines which exist or may be created “. ${ }^{33}$ Takový postoj je možné vnímat jako referenční pro počátek algoritmické kompozice a CAC a současně koresponduje s celou řadou soudobých postojů. Namátkou je možné uvést např. skladatele, muzikologa a spolupracovníka Institut de Recherche et Coordination Acoustique/ Musique Karima Haddada, podle kterého „The algorithms may be seen as the executive part of the composer's idea, also deterministic when data proposal is added, with dynamic decisional potential that models the propositional data to its own creative role “ ${ }^{34}$ Níže uvedený př́klad 2a/b/c pak ilustruje část ,algorithmic

31 ADORNO, T.W. Estetická teorie. Praha: Panglos, 1997, s. 53.

32 Eventuálně je možné hovořit o druhé vývojové fázi serialismu, ve které již pracují skladatelé s použitím výrazně individualizovaných kompozičních metod, např. Pierre Boulez a jeho metoda násobení homogenního komplexu tónových výšek, viz BOULEZ, op. cit., s.198.

XENAKIS, Iannis. Formalized Music: Thought nd Mathematics in Composition. BloomingtonIndiana University Press, 1971, s.132.

34 HADDAD, Karim. TimeSculpt in OpenMusic. In The OM composer's book Vol.1. Carlos Agon - Gérard Assayag - Jean Bresson (eds.). Le Vallier/Paris: Editions Delatour France / 
Strategies ${ }^{\text {“35 }}$ skladby A Collection of Caprices (2002) dalšího, a stejně tak namátkou vybraného skladatele a hudebního teoretika Paula Nauerta.

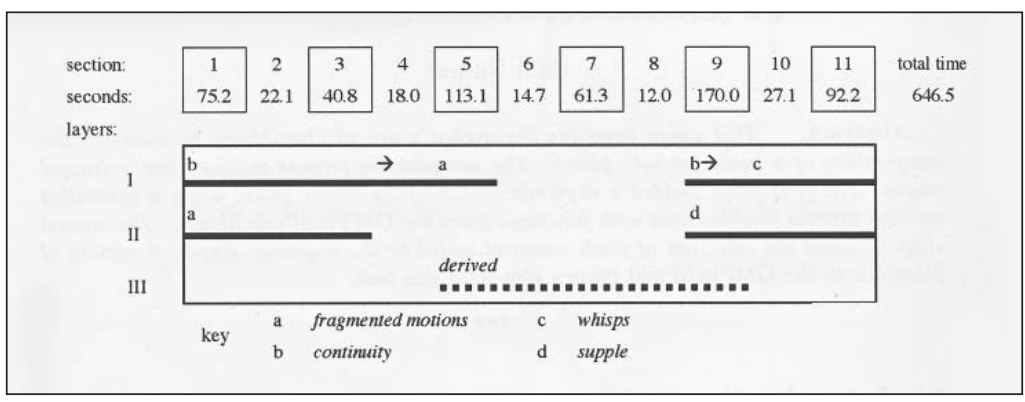

Př. 2a. Paul Nauert, A Collection of Caprices (2002), „section plane“ a budoucí „rhytmic sketch“ pro 11 částí (section) skladby s využitím geometrické série $12 \times(49 / 40)^{\mathrm{n}}$. Zdroj: NAUERT, Paul. Algorithmic Strategies in „A Collection of Caprices“. In The OM composer's book Vol. 1., 2006, s. 164.

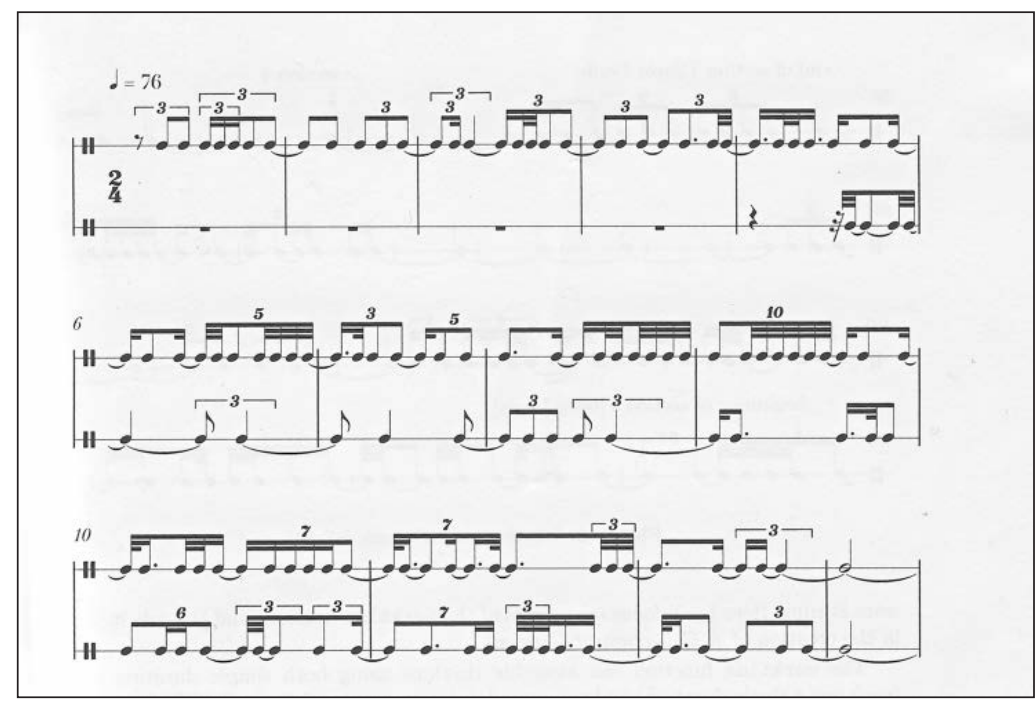

Př. 2b. Paul Nauert, A Collection of Caprices, přepis „,section plane“ a vzniklý „,rhytmic sketch“ pro takty 1-13. Zdroj: NAUERT, op. cit., s. 165.

Ircam, 2006, str. 61

35 NAUERT, Paul. Algorithmic Strategies in „A Collection of Caprices“. In The OM composer's book Vol. 1. Carlos Agon - Gérard Assayag - Jean Bresson (eds.). Le Vallier/Paris: Editions Delatour France / Ircam, 2006, s. 163 


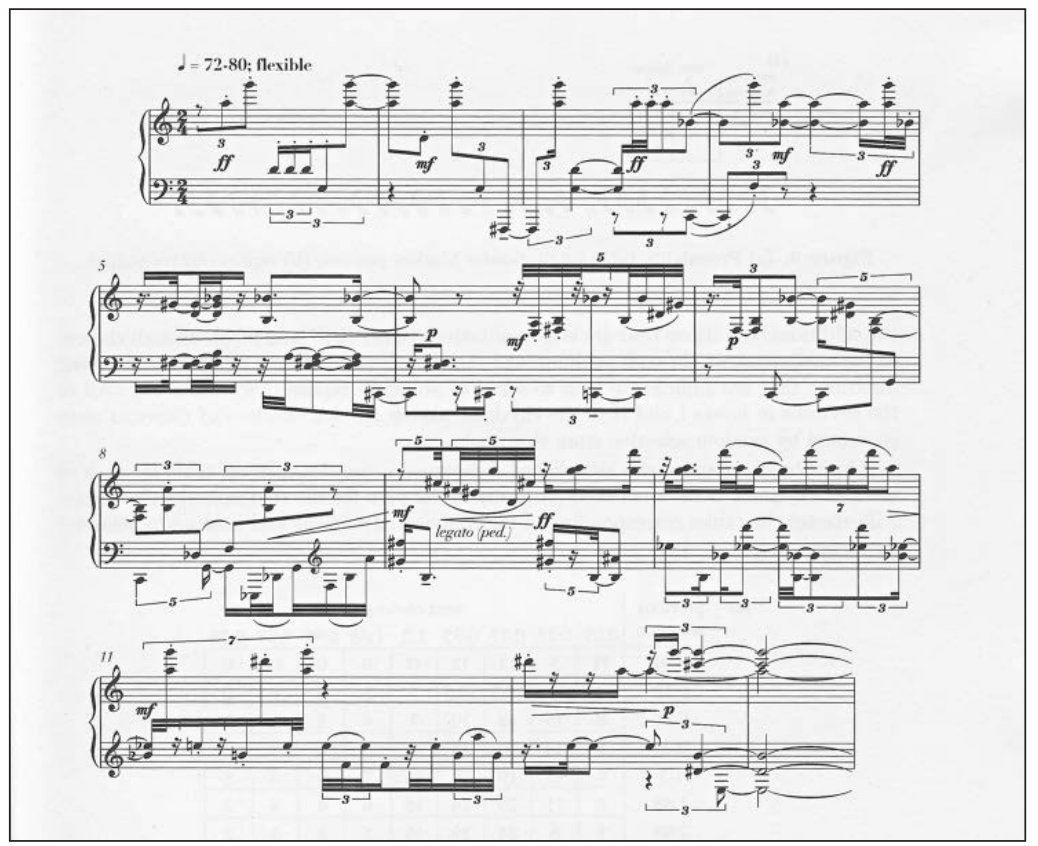

Př. 2c. Paul Nauert, A Collection of Caprices, odpovídající část partitury (t.1-13) s využitím výše uvedeného rytmického plánu. Zdroj: NAUERT, op. cit., s. 167.

\section{Poznámka k algoritmické a seriální kompozici}

Nezbytnou součástí seriálně pracujícího skladatele je tvorba série, jejíž architektura je, anebo by měla být, Boulezovými slovy již shora řečeno, zárodkem hierarchie kompozice. Takovou činnost lze vnímat jako tvůrčí akt, který musí skladatel, na rozdíl od tonálně pracujícího skladatel, provést ještě před zahájením vlastního komponování. $\mathrm{V}$ př́ípadě algoritmické kompozice je v okamžiku, kdy se skladatel rozhodne vytvořit vlastní anebo upravit stávající algoritmus, situace stejná. I zde nejdříve vzniká systém formování, který by v ideálním př́ípadě měl být schopen generovat hudební strukturu zamýšlené, s největší pravděpodobností vysoké, estetické hodnoty. V obou případech je tedy výrazně posílena koncepční povaha kompoziční činnosti a povaha kompozice jako koherentního, komplexního a pokud možno bezrozporného estetického ${ }^{36}$ systému.

36 Pojem „estetický“ je zde vnímám takřka jako synonymum pojmu „kompoziční metoda“, se kterou je neodmyslitelně a př́činně spjatý. 


\section{Závěr}

Algoritmická kompozice představuje celou řadu blíže neurčených, autonomních kompozičních postupů a souvisejících hudebně estetických postojů. Algoritmickou kompozici lze chápat jako projev postmoderny a to díky pluralitě, kterou poskytuje ve volbě metodických procedur. Jako algoritmus je možné použít jakákoliv data, dle skladatele způsobilá fungovat jako „systém formování“. Jeho použití je také jediným a současně nutným aktem naplňujícím podstatu algoritmického komponování. Vzhledem k tomu, že historie Západní hudební kompozice je historií více či méně mechanizovaného algoritmického uvažování podpořeného deterministickým, formotvorným aspektem tonality ovlivňujícím kompoziční metody a strukturu vzniklé kompozice, je možné algoritmickou kompozici nahlížet jako jev představující abstrahování samotné povahy kompozice jako takové a tedy jako jev, který neztrácí vazbu nejen s uměním moderním, ale ani s uměním předmoderním. V rámci diskursu o postmoderně se pak algoritmická kompozice jeví jako jev nabízející exoterické, pluralitní naplnění dřive esoterní moderny.

Petr Haas (215418@mail.muni.cz), Ústav hudební vědy, Filozofická fakulta, Masarykova univerzita, Brno.

\section{ABSTRACT ALGORITHMIC COMPOSITION, COMPUTER-AIDED COMPOSI- TION AND POSTMODERN PLURALISM}

This article deal with algorithmic and related computer-aided composition. The conclusions of philosophy and general art theory are used to explain the algorithmic composition as a manifestation of postmodernism and at the same time the article offers a view on the algorithmic composing as on a phenomenon, which corresponds with the basic character of Western composition.

\section{Key words}

algorithmic composition, computer-aided composition, computer- assisted composition, postmodernism, 20th century music

\section{Bibliography}

ADORNO, T.W. Estetická teorie. Praha: Panglos, 1997.

ALSOP, Roger. Exploring the Self Through Algorithmic Composition. Leonardo music journal, 1999, roč. 9, s. 89-94.

ANDRES, Torsten + MIRANDA, Eduardo Reck. Interfacing Manual and Machine Composition. Contemporary Music Review, 2009, roč. 28, č. 2, s. 133-147.

ASSAYAG, G - RUEDA, C. - LAURSON, M. - AGON, C. - DELERUE. Computer - Assisted Composition at IRCAM: From ParchWork to OpenMusic. Computer Music Journal, 1999, roč.23, č.3, s. 59-72.

ASSAYAG, Gérard. Computer Assisted Composition today. 1st Symposium on music and compu- 
ters: „Applications on Contemporary Music Creation: Esthetic and Technical Aspects“. Corfu, 23-25 $5^{\text {th }}$ October, 1998.

ASSAYAG, Gérard - DAUBRESSE, Eric. Technologiy and Creation - The Creative Evolution. Contemporary Music Review, roč. 19, č. 2, 2000, s. $61-80$.

BOULEZ, Pierre. Dnešní hudební myšlení. In Nové cesty hudby, sborník studií o novodobých skladebných směrech a vědeckých názorech na hudbu. Praha: Státní hudební nakladatelství, 1964, s. $136-168$.

BRESSON, Jean - GIAVITTO, Louis. A reactive extension of the OpenMusic visual programming language. Journal of Visual Languages and Computing, 2014, č. 25, s. 363375.

BRUCE, Jacob, L.Algorithmic Composition as a Model of Creativity. In Organised Sound, 2013. S. $157-165$.

BURNS, Kristine H. The history and development of algorithms in music composition, 1957-1993: Doctoral dissertation. Muncie: Ball State University, School of Music, 1994.

DLOUHÝ, Dan. Počitačem podporovaná algoritmická kompozice: Habilitační práce. Brno: JAMU, 2013.

EDWARDS, Michael. Algorithmic Composition: Computational Thinkingin Music. Communications of the acm, 2011, roč. 54, č.7, s. 58 -67.

HARLEY, James. Generative Proces in Algorithmic Composition: Chaos and Music. Leonardo, 1995 , roč. 28, č. 3, s. 221-224.

HARVEY, Jonathan. Spectralism. Contemporary Music Review, 2000, roč. 19, č. 3, s. 11-14.

HONS, Miloš. K vývoji formového myšlení období rozpadu tonality na počátku 20. století. In K aktuálním otázkám hudební teorie. Praha: AMU, 2000, s.47-53.

KELLER, Damián - FERNEYHOUGH, Brian. Analysis by Modeling: Xenakis's ST/10-1 080262. Journal of New Music Research, 2004, roč. 33, č. 2, s. 161-171.

LYOTARD, Jean Francois. O postmodernismu. Praha: Filosofický ústav AV ČR, 1994.

MEDEK, Ivo - PIŇOS, Alois. Řád hudebni kompozice a prostředky jeho výstavby. Brno: JAMU, 2004.

NIERHAUS, Gerhard. Algorithmic Composition: Paradigms of Automated Music Generation. Wien: Springer, 2009.

PECHAR, Jiří. O postmodernismu, smyslu umění a právu na vlastní př́běh. Úvodní studie k publikaci LYOTARD, Jean Francois. O postmodernismu. Praha: Filosofický ústav AV ČR, 1994, s. 5. PETŘíČEK, Miroslav. Úvod do současné filosofie. Praha: Herrman a synové, 1997.

SCHÖNBERG, Arnold. Styl a idea. Praha: Arbor vitae, 2004.

SPIES, Claudio. Note from Terra Firma. Perspectives of New Music, 1988, roč. 26, č. 1, s. 210-212. TIPEI, Sever. The Computer: A Composer's CollaboratorAuthor (s). Leonardo, 1989, roč. 22, č. 2 , s. $189-195$.

WELSCH, Wolfgang. Naše postmoderní doba. Praha: Zvon, 1994.

XENAKIS, Iannis. Formalized Music: Thought nd Mathematics in Composition. Bloomington: Indiana University Press, 1971.

The OM composer's book Vol.1. Carlos Agon - Gérard Assayag - Jean Bresson (eds.). Le Vallier/ Paris: Editions Delatour France / Ircam, 2006. 
